\title{
"A comparative analysis of value management practices between consumer and construction based firms"
}

\begin{tabular}{|c|c|}
\hline AUTHORS & $\begin{array}{l}\text { Vitalis Ndu } \\
\text { Emmanuel Agbaeze (D https://orcid.org/0000-0002-8952-7612 } \\
\text { Emmanuel Arisi-Nwugballa } \\
\text { Henry Okwo (D) https://orcid.org/0000-0002-4994-8199 }\end{array}$ \\
\hline ARTICLE INFO & $\begin{array}{l}\text { Vitalis Ndu, Emmanuel Agbaeze, Emmanuel Arisi-Nwugballa and Henry Okwo } \\
\text { (2019). A comparative analysis of value management practices between } \\
\text { consumer and construction based firms. Problems and Perspectives in } \\
\text { Management, 17(3), 280-292. doi:10.21511/ppm.17(3).2019.23 }\end{array}$ \\
\hline DOI & http://dx.doi.org/10.21511/ppm.17(3).2019.23 \\
\hline RELEASED ON & Friday, 30 August 2019 \\
\hline RECEIVED ON & Wednesday, 03 April 2019 \\
\hline ACCEPTED ON & Wednesday, 17 July 2019 \\
\hline LICENSE & $\begin{array}{l}(c) E Y \\
\text { This work is licensed under a Creative Commons Attribution } 4.0 \text { International } \\
\text { License }\end{array}$ \\
\hline JOURNAL & "Problems and Perspectives in Management" \\
\hline ISSN PRINT & $1727-7051$ \\
\hline ISSN ONLINE & $1810-5467$ \\
\hline PUBLISHER & LLC "Consulting Publishing Company "Business Perspectives" \\
\hline FOUNDER & LLC "Consulting Publishing Company "Business Perspectives" \\
\hline
\end{tabular}

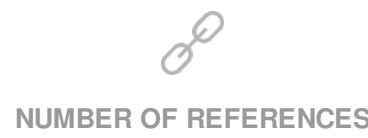

36
NUMBER OF FIGURES

6
NUMBER OF TABLES

8

(C) The author(s) 2022. This publication is an open access article. 


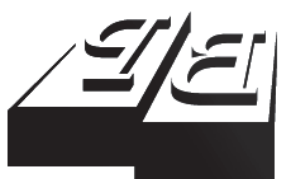

BUSINESS PERSPECTIVES

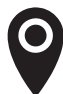

LLC "CPC "Business Perspectives" Hryhorii Skovoroda lane, 10, Sumy, 40022, Ukraine

www.businessperspectives.org

Received on: $3^{\text {rd }}$ of April, 2019 Accepted on: $17^{\text {th }}$ of July, 2019

C) Vitalis Ndu, Emmanuel Agbaeze, Emmanuel Arisi-Nwugballa, Henry Okwo, 2019

Vitalis Ndu, Doctoral Researcher, Faculty of Business Administration, Department of Management, University of Nigeria, Nigeria

Emmanuel Agbaeze, Ph.D., Senior Lecturer, Faculty of Business Administration, Department of Management, University of Nigeria, Nigeria.

Emmanuel Arisi-Nwugballa, Ph.D., Senior Lecturer, Department of Business Management, Faculty of Management Sciences, Ebonyi State University, Nigeria.

Henry Okwo, Ph.D. Student, Department of Management, Faculty of Business Administration, University of Nigeria, Nigeria.

\section{(ㄷ)(ㄱ)}

This is an Open Access article, distributed under the terms of the Creative Commons Attribution 4.0 International license, which permits unrestricted re-use, distribution, and reproduction in any medium, provided the original work is properly cited.
Vitalis Ndu (Nigeria), Emmanuel Agbaeze (Nigeria),

Emmanuel Arisi-Nwugballa (Nigeria), Henry Okwo (Nigeria)

\begin{abstract}
The use of value management tools in non-management and non-business domains appears to be high, as exemplified by numerous studies conducted on the subject matter in the construction based disciplines, but understanding how such essential tool works in the consumer based domains seems lacking, this study becomes relevant in this regard. The aim of the study therefore is to understand how consumer based and construction based firms differ with regard to the use, focus and control of value management on a firm-by-firm basis, locational basis and on the basis of industrial typology. The researchers adopted a survey research design using a 16-item questionnaire instrument administered to 509 respondents across 10 firms: 5 being consumer and the other 5 being construction based firms. The formulated hypotheses were tested using Kruskal-Wallis and Mann Whitney's U-test for non-parametric comparisons. The results obtained showed that consumer based firms ranked higher than construction based firms, both on a firm-by-firm $(\mathrm{CSB}=256.9, \mathrm{CTB}=247.4$, p@0.005; CSB=264.6, $\mathrm{CTB}=234.3$, $\mathrm{p} @ 0.011)$ for focus and control, respectively, and on an industrial type $(\mathrm{CSB}=267.65, \mathrm{CTB}=235.93, \mathrm{p} @ 0.017 ; \mathrm{CSB}=268.71, \mathrm{CTB}=234.33$, $\mathrm{p} @ 0.009 ; \mathrm{CSB}=$ 269.21, CTB = 233.58, p@0.007; CSB = 268.38, CTB = 234.83, p@0.011) comparison basis on actual usage, perceived usage, focus and control of value management, respectively. For the locational difference, there were no statistical significance. The study concludes that there is a case for a multidisciplinary study of value management as it appears more present in consumer than construction based firms.
\end{abstract}

\section{Keywords}

value management usage, value management focus, value management control, Kruskal-Wallis test, MannWhitney's U-test, comparison

JEL Classification L23, L70, L67, M11

\section{INTRODUCTION}

Value management was introduced in the United States in 1940s (Gillier, Hooge, \& Piat, 2014; Spaulding, Bridge, \& Skitmore, 2007). It owes its actual definition to Lawrence D. Miles. Miles developed this concept during the Second World War, although he was not a lieutenant in the war, but was an employee of the firm - General Electric. The issue at that time was the desire of General Electric to keep functionality and quality high at the lowest cost possible due to looming scarcity of material input to execute the war for the United States Department of Defense. The emphasis for Miles at that time therefore was the dilemma of balancing function and cost (Kassa, 2018). Although in its earliest form it almost lost steam as other cost efficient tools were being used by corporations and government all around the world; in order to reduce cost (Mcgeorge \& Angela, 2002). The tools which competed with value management were the Total Quality Management (TQM), Just-In-Time Production (JIT) and Activity Based Costing (ABC) (Fong, Shen, \& Cheng, 2001). Not long from this pressured moment, 
value management regained prominence and was first applied outside the US as value engineering in the United Kingdom (Fong et al., 2001), and after then had been known as value analysis in some parlance, but mostly the interchange between its use as value engineering and value management is what persist today (Gillier et al., 2014; Mcgeorge \& Angela, 2002). Although its noteworthy to state that its operations and usage in the United Kingdom is much more prevalent than in the United States, laying credence to the value management-location argument (Ellis, Wood, \& Keel, 2005; Kelly \& Male, 1993; Kelly, Male, \& Graham, 2015).

In consonance with the location argument earlier stated, value management or value engineering is also an issue on the basis of specialty as described in construction, engineering, project management and management sciences (Douglas \& Lubbe, 2006; Dumond, 2000; Kissi, Boateng, \& Badu, 2016; Leung, Ng, \& Cheung, 2002; Perera, Hayles, \& Kerlin, 2011; Strack \& Villis, 2002; Thiry, 2001). It is also an argument on the basis of location-developed country, industrially savvy environment and developing or low income economies (Aghimien, Oke, \& Aigbavboa, 2018; Charles, Nasiri, \& Hammad, 2017). Some more issues are that the emphasis on value management or value engineering is biased on the basis of the engineering specialty and mostly amongst developed economies creating a practice and theoretical gap in other disciplines, and while we do not deny the fact that construction and engineering discipline embodies value management, we wish to make a case for the management sciences discipline as others have proposed (Gillier et al., 2014), and much more, making it emphatic that value management is best as a multidisciplinary subject. This is so because value management which is clearly a management concept (Hyatali \& Pun, 2015) has been regularly termed to mean a concept in either quantity surveying or construction engineering (Bowen, Cattell, Edwards, \& Jay, 2010; Oke \& Ogunsemi, 2011; Oke, Aghimien, \& Olatunji, 2015; Perera et al., 2011).

\section{REVIEW OF RELATED LITERATURE}

Value management or value engineering as a concept has been abundantly studied. This concept simply implies different things to different authors. It has been traditionally domiciled in the engineering or construction literature until recently, now finding its way to other aspects of value scholarship like health and behavioral sciences (Dumond, 2000). In describing what value management means and entails, one would also have to state that it generally describes how value can be maximized by considering the interplay between functional performance and the cost of resources (Bowen, Edwards, \& Cattell, 2009; Kissi et al., 2016; Perera et al., 2011). This description implies that in attaining value, the two most essential components are functionality of a process, product or service and the minimization of cost (Dhir, 1987; Kassa, 2018). Also, it is apt to state that when functional performance is emphasized, that covers the concern of stakeholders or contributors of capital and also customers or clients. In this case, when functionality is guaranteed with the process of product or service development, all parties per- ceive the process to be one with the potential for deriving benefits, whether in the forms of profit to stakeholders or quality of products or services for clients and customers. On the other throng, functionality being guaranteed without an adequate consideration of reducing or minimizing cost does not prove to be a proper value creation, co-creation or management process (Fallon, 1961). It is premised on this that we have value being interpreted as:

$$
\text { Value }=\frac{\text { Functionality }}{\text { Cost of resources }} \text {. }
$$

As had been earlier stated in this paper, we intend to compare how construction or engineering firms' value management practices relate to the practices on the consumer based firms. In so doing, we further opine that the value management process is on that is primarily a management rather than engineering process. We support the opinion and postulation of Dumond in 2000 (Dumond, 2000) on the view that the entire value management process is one that has as its objective the fulfillment of customers need through a management based process. 
Here, we see the chain of value management as an organizational strategy and initiative, which begins by defining an organizational mission and strategy. At this stage, managers set out to plan the set-up of organizational systems, that is, the strategy would lead to developing organizational systems, and this would encompass training of the organization's manpower to be readily equipped with the required skill, knowledge and abilities; designing the job and specifying tasks to be performed by these workers; creating platforms to manage the interface relationships that a social system would produce; setting performance measurement yardsticks upon which actual and expected outcomes would be compared; and setting up the organizational information systems - all of these being products of the organizational systems created by management.

The sequence leads to the next step of process management. It is at this stage that we argue, in our modified model, that the value engineering process explained by scholars in the construction and economic engineering field of study is mostly infused in this process management stage.

All of these should then lead to the ultimate good of the customers - customer success. As the key to organizational continuity and well-being, customer success is also a goal of a typical value management process. We argue that firms that engage in value management with the 'engineering' mindset of just efficiently concluding projects, without the customer or client in mind, would do poorly. We state that if companies have their eyes on market related customer indices like customer satisfaction, product or service quality, customer service orientation, market orientation, or customer needs, such companies stand a better chance of soaring better in terms of the actual value management practice.

To shed further empirical and theoretical light on this study discourse, it is prime to state that the question of ownership still appears to be an issue on the discourse of value management research (Green \& Liu, 2007). While it appears that engineering or construction based disciplines such as project management, construction man- agement, quantity surveying, property development, building technology, actuarial and architectural management have been enriched by studies on value management and engineering (Spaulding et al., 2007; Bowen et al., 2010; Giller et al., 2014; Kissi et al., 2016; Charles et al., 2017; Aghimien et al., 2018) and the use and practices associated there with, other more social leaning disciplines seem to have started taking notice of the need to make their own contribution to the value management discourse, being that value management is basically concerned with balancing function and cost, while not ignoring safety and quality. These are the key terms in value management and cannot be said to solely belong to the domain of construction only. It is also rife to say that other studies in non-construction disciplines have also been conducted, these are in areas on tourism management, business management, marketing science and supply-chain management (Leung et al., 2002; Strack \& Villis, 2002; Douglas \& Lubbe, 2006; Oke et al., 2015; Verhoef et al., 2015). The delineation of value management as an engineering concept may have been done unconsciously, but it has no doubt been the case. This unconscious attribution of a concept to an area of discipline can be explained by the anchor-network theory of Bruno Latour, developed in 2005.

Using the phrase "reassembling the social", Latour (2005) describes the fact that social groups of persons describe how concepts are digested and attributed. The theory implies that the issue of delineating a subject of study to one disciplinary section and not the other is explained by the actor-network mechanism that underlines every social interaction. This theory by Latour simply gives explanation as to how phenomena are set and enhanced. The theory argues that the network of ideas which defines and delineates a concept are premised upon the activities of certain social actors who must have decided to make them so. We argue from a social science standpoint that while most studies on value management and value engineering are domiciled in the narrow construction discipline, the surge of studies in the social sciences domain on value management would inadvertently balance the concept as a multidisciplinary rather than a monocentric subject. 


\section{SELECT EMPIRICAL REVIEWS}

Hashempour, Rostaupour, and Belyati (2015) conducted a study on how the value management tool of brainstorming could be used as a strategy to improve or influence the ability of individuals in Iran. The study was set in an educational environment where the ability of advanced learners was being measured. The aim of the study was ascertaining how brainstorming, its subcategories of outlining, listing, answer and question as pre-writing strategies were used to improving the respondents writing development. The target respondents were 60 Iranian advanced learners, which were subgrouped on the basis of gender. A survey using a structured questionnaire formed the basis of data collection. Using two groups of experimental and control, the findings could not ascertain a statistically significant effect of brainstorming exercise of the writing development of respondents whether on the basis of gender, experimental groupings or sub-categorization. Recommendations were borne out of obvious limitations of the study, which was that brainstorming and any accompanying value management activity should be carried out within a reasonable space of time to result in significant improvements.

Oke, Aghimein, and Olatunji (2015) conducted a study on how economic sustainability could be improved with the implementation of value management in the building construction sector in Nigeria. The study was premised on the dwindling fortunes of building construction in Nigeria and aimed on a case-by-case basis to ascertain the perceived benefits and issues surrounding the use of value management as a tool for economic sustainability. Four case-by-case projects were set up at a 40 hour value management location where facilitators and members of the team were trained and expected to carry out clear value management tasks. The first project was for building what seemed like a community hall, which could be hired for social and religious gatherings, this team had 6 members. The second was construction of a two bedroom bungalow apartment; the team had 5 members. The third was the construction of a single bedroom having a security gate house. The team had 5 members. For the fourth, with 6 members, the project was the construction of a church building. At the end of the experimental exercises, all teams achieved economic sustainability, because the initial layout of fund reduced by 28,38 , 31 , and $15 \%$, respectively, for the four teams.

Ezezue (2015) is a conference paper presented at the United Arab Emirates in challenges and prospects of value management amongst manufacturing companies in Nigeria stated the objectives that were concerned with the hurdles manufacturing firms in an large-market developing economy face, and how these hurdles can be mitigated, while improving product and process quality within the firms. With a sample of 375 respondents from 20 manufacturing firms, the major impediment for firms was the orientation and notion that they had on the practice of value management, while the product quality and process quality aspect were enhanced for firms with high value management practice and low for those who didn't practice value management. The study emphasized on value management re-orientation as a predictor for future cost minimization outcomes amongst manufacturing firms.

Amoush (2015) conducted a study on how brainstorming as a value management tool could be deployed in order to enhance the performance of individuals at the Balqa Applied University in Jordan. The specific objectives here were to ascertain if there was any statistically significant group difference on teaching strategy between a brainstorming prone and traditionally taught group, and whether such difference also occurs on the basis of the gender variable. The methodology was experimental with two groups of 40 each, that is a sample of 80: 40 experimental cases and 40 control cases. The method followed was the use of a protest-strategies instruction-posttest-scoring. The findings showed that while there was a statistically significant difference, performance for the brainstorming group was enhanced in the both cases. The conclusion here bothers on the positive effect value management has on processes that may not be purely construction or engineering based.

Although these works by Amoush (2015) and Hashempour, Rostampour, and Behjat (2015) appear as education based efforts, a closer look shows that since brainstorming could be a part of the value management tools, then its use only 
implies the multidisciplinary dimensions of value management.

Our aim therefore is to probe value management practices in the context of a developing economy Nigeria, and in a comparative manner, having equal numbers of both construction/engineering and consumer based firms.

In the light of these, we hypothesize the following:

$H_{1}: \quad$ The level of usage, focus and control of value management practices is statistically higher amongst consumer rather than construction based firms on a firm by firm basis.

$H_{1}$ : The level of usage, focus and control of value management practices is statistically higher amongst consumer rather than construction based firms on the basis of firm location.

$H_{1}: \quad$ The level of usage, focus and control of value management practices is statistically higher amongst consumer rather than construction based firms on the basis of typology.

\section{METHODOLOGY}

The study required the use of a test that would be able to establish the set intention, which was to consider the data trend on value management in a comparative nature, that is, determining whether there is statistical difference on value management practice amongst firms based on their unique operation, their location and their industrial typology, being either consumer based (CSBs) or construction based (CTBs). The data set on value management is mostly non-parametric as it hardly passes the tests of homogeneity of variance, normality and heteroskedasticity, amongst other assumptions for parametric analysis (Hayes, 2018). This is so because the items that are usually used to measure value management practice have not been adequately studied as a behavioral concept, and therefore lacks the appropriate psycho-metric valuation required for standardized question items that could meet the parametric analysis criterion. So, we adopted the use of the non-parametric equivalent for the Analysis of Variance
(ANOVA), which is the Kruskal-Wallis $\mathrm{H}$ Test for independent samples with more than two groups (Feir-Walsh \& Toothaker, 1974), this is for individual firm and location, while we used the Mann-Whitney's U Test for the sample with just two groups (Mann \& Whitney, 1947; B. Zhang \& Y. Zhang, 2009). These tests are known to be statistically appropriate for studies of this nature, where the essence is to establish group difference (Thangavelu \& Brunner, 2007).

\section{RESULTS}

These data were collected from ten firms across the five states that make up Eastern Nigeria. These firms are Coca-Cola Nigeria Plc., Aba Branch in Abia State; Masters Energy Head Office, at Uturu, Abia State; Orange Drugs and SABMiller at Onitsha, Anambra State; Innoson Technical and Industrial Company and Nigerian Breweries in Enugu, Enugu State; Ebonyi Pipes at Ezzamgbo and Iboko Rice Mill at Izzi, Ebonyi State; and Ogbuawa Motorcycles and Ibeto Petrochemicals in Orlu in Imo State. These firms were selected on a random basis, having 5 as construction/engineering firms and the other 5 as consumer based firms. During the pilot study, a total of 563 respondents were targeted, but 509 responded and returned, and although there were a couple of missing cases, these were infinitesimal and did not warrant a total rejection (Curran, 2016). The response rate therefore was $90.41 \%$. The respondents were only heads of engineering units in the firms, managerial staff and other project managers; these are in consonance with suggested respondents for studies of this nature (Bowen et al., 2010; Perera et al., 2011). A structured questionnaire instrument was distributed having 16 question items only, but implicit consideration was given to note the location a particular set of questionnaires had been distributed, the particular firm, and the industrial leaning of such firm. These helped in the subsequent stratification of the data set on the basis of organization, location and industry type. The main question items were adapted from Perera et al. (2011) and Bowen et al. (2010). The items measured the level of value management intensity that could be attributable to a firm. The measure thereof was the actual 
use of value management, the perceived use of value management, the level of focus on value management tools and the means of handling value management. Each of these measures had four items each; these could be clearly seen in the data file (as attached in this submission).

For parsimony, we also do state that the firms, which are a make-up of both local and multinationals were analyzed in no particular order but are marked with the acronyms: CSB (consumer based firms) and CTB (construction based firms). These firms are:

\begin{tabular}{c:c}
\hline Consumer based firms & Construction based firms \\
\hline $\begin{array}{c}\text { Coca-Cola Bottling Company } \\
\text { (CSB1) }\end{array}$ & Masters Energy (CTB1) \\
\hline Orange Drugs (CSB2) & $\begin{array}{c}\text { Innoson Technical and Industrial } \\
\text { Company (CTB2) }\end{array}$ \\
\hdashline SABMiller Company (CSB3) & Ebonyi Pipes (CTB3) \\
\hline Nigerian Breweries (CSB4) & Ogbuawa Motorcycles (CTB4) \\
\hline Iboko Rice Mills (CSB5) & Ibeto Petrochemicals (CTB5) \\
\hline
\end{tabular}

\section{Hypotheses test}

\section{Category 1. Firm type}

Table 1. Descriptive statistics on the collation of question items based on firm type

\begin{tabular}{|c|c|c|c|c|c|}
\hline \multirow{2}{*}{$\begin{array}{c}\text { Parameters } \\
\text { accessed }\end{array}$} & \multicolumn{5}{|c|}{ Source: SPSS (v. 2} \\
\hline & $\mathbf{N}$ & Mean & $\begin{array}{c}\text { Std. } \\
\text { deviation }\end{array}$ & Min & $\operatorname{Max}$ \\
\hline $\begin{array}{l}\text { Total sum of } \\
\text { actual usage } \\
\text { of value } \\
\text { management } \\
\text { per firm }\end{array}$ & 509 & 12.3065 & 2.98229 & 5.00 & 20.00 \\
\hline $\begin{array}{l}\text { Total sum of } \\
\text { perceived } \\
\text { usage of value } \\
\text { management } \\
\text { per firm }\end{array}$ & 509 & 12.4695 & 3.02574 & 4.00 & 20.00 \\
\hline $\begin{array}{l}\text { Total sum of } \\
\text { focus on value } \\
\text { management } \\
\text { per firm }\end{array}$ & 509 & 12.3674 & 3.01058 & 5.00 & 20.00 \\
\hline $\begin{array}{l}\text { Total sum of } \\
\text { control of value } \\
\text { management } \\
\text { per firm }\end{array}$ & 509 & 12.3360 & 3.13086 & 5.00 & 20.00 \\
\hline Name of firm & 509 & 4.4813 & 2.47629 & 1.00 & 10.00 \\
\hline
\end{tabular}

Table 1 shows the aggregated mean and standard deviation of the question items for the value management practices.
Table 2. Mean rank of value management practices per firm

Source: Field survey (2018)/SPSS (v. 20)

\section{Actual usage of value management per firm}

Perceived usage of value management per firm

Focus on value management per firm

Control of value management per firm

\begin{tabular}{|c|c|c|}
\hline $\begin{array}{l}\text { Firm } \\
\text { group }\end{array}$ & $\mathbf{N}$ & $\begin{array}{c}\text { Mean } \\
\text { rank }\end{array}$ \\
\hline \multicolumn{3}{|c|}{ Section 1} \\
\hline CSB1 & 78 & 291.21 \\
\hline CSB4 & 116 & 278.19 \\
\hline CSB5 & 11 & 259.09 \\
\hline CSB2 & 58 & 238.50 \\
\hline CSB3 & 43 & 238.01 \\
\hline \multicolumn{3}{|c|}{ Group mean $=261$} \\
\hline CTB5 & 10 & 277.30 \\
\hline CTB3 & 28 & 263.93 \\
\hline CTB2 & 65 & 244.62 \\
\hline CTB1 & 64 & 228.33 \\
\hline CTB4 & 36 & 200.50 \\
\hline \multicolumn{3}{|c|}{ Group mean $=242.9$} \\
\hline \multicolumn{3}{|c|}{ Section 2} \\
\hline CSB4 & 116 & 286.49 \\
\hline CSB1 & 78 & 271.81 \\
\hline CSB5 & 11 & 261.73 \\
\hline CSB2 & 58 & 260.86 \\
\hline CSB3 & 43 & 227.49 \\
\hline \multicolumn{3}{|c|}{ Group mean $=261.7$} \\
\hline CTB4 & 36 & 243.42 \\
\hline CTB1 & 64 & 240.60 \\
\hline CTB2 & 65 & 233.11 \\
\hline CTB3 & 28 & 230.79 \\
\hline CTB5 & 10 & 179.40 \\
\hline \multicolumn{3}{|c|}{ Group mean $=225.5$} \\
\hline \multicolumn{3}{|c|}{ Section 3} \\
\hline CSB1 & 78 & 290.62 \\
\hline CSB4 & 116 & 278.10 \\
\hline CSB2 & 58 & 268.51 \\
\hline CSB5 & 11 & 229.73 \\
\hline CSB3 & 43 & 217.44 \\
\hline \multicolumn{3}{|c|}{ Group mean $=256.9$} \\
\hline CTB4 & 36 & 284.07 \\
\hline CTB3 & 28 & 253.60 \\
\hline CTB1 & 64 & 243.32 \\
\hline CTB5 & 10 & 253.60 \\
\hline СTB2 & 65 & 202.55 \\
\hline \multicolumn{3}{|c|}{ Group mean = 247.4} \\
\hline \multicolumn{3}{|c|}{ Section 4} \\
\hline CSB5 & 11 & 291.86 \\
\hline CSB4 & 116 & 289.59 \\
\hline CSB1 & 78 & 286.06 \\
\hline CSB3 & 43 & 227.84 \\
\hline CSB2 & 58 & 227.78 \\
\hline \multicolumn{3}{|c|}{ Group mean $=264.6$} \\
\hline CTB4 & 36 & 271.33 \\
\hline CTB3 & 28 & 243.84 \\
\hline CTB1 & 64 & 226.39 \\
\hline CTB2 & 65 & 223.40 \\
\hline CTB5 & 10 & 206.50 \\
\hline \multicolumn{3}{|c|}{ Group mean $=234.3$} \\
\hline
\end{tabular}

Table 2 describes the mean ranks as internally estimated from the Kruskal-Wallis $\mathrm{H}$ computation. 


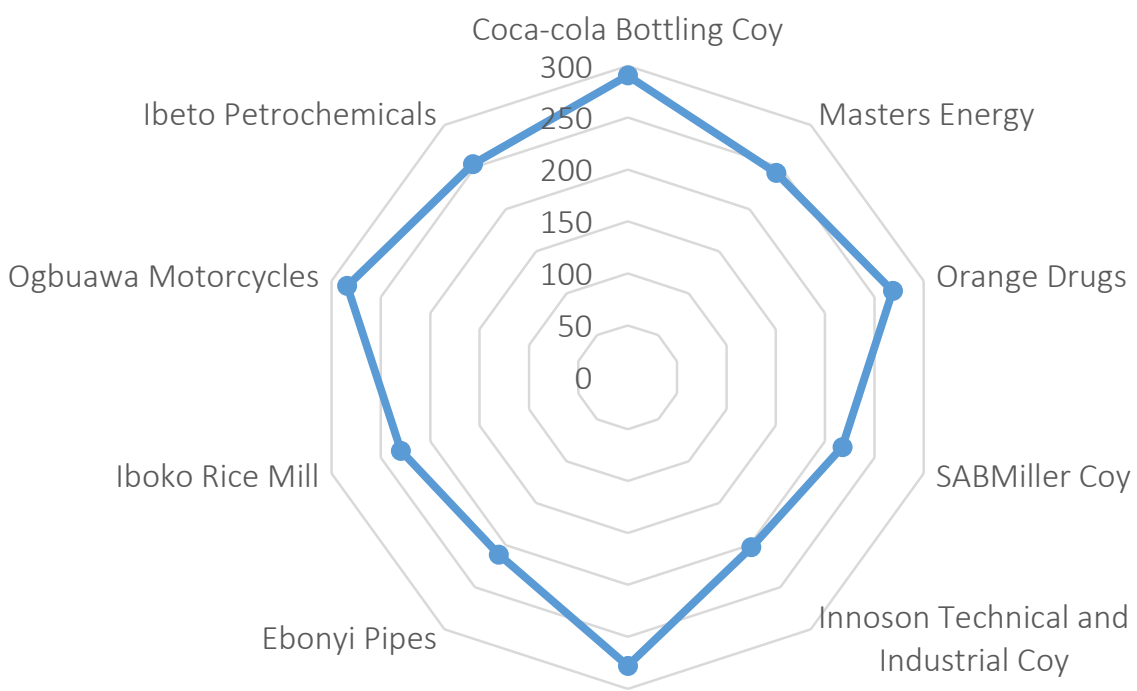

Nigerian Breweries

Figure 1. "Focus level" mean rank by Firm type

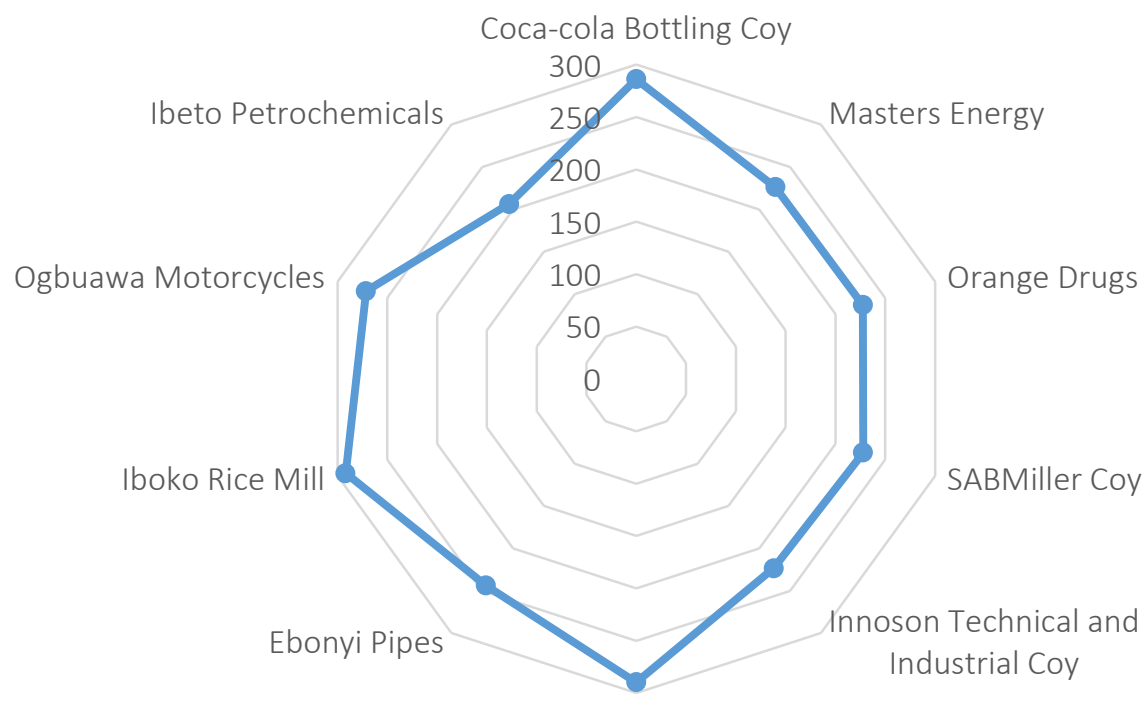

Nigerian Breweries

Figure 2. "Level of control" mean rank by firm type

Table 3. Kruskal-Wallis H result on group difference

Source: SPSS (v. 20).

\begin{tabular}{|c|c|c|c|c|}
\hline Results & $\begin{array}{l}\text { Total sum of actual } \\
\text { usage of value } \\
\text { management per firm }\end{array}$ & $\begin{array}{c}\text { Total sum of perceived } \\
\text { usage of value } \\
\text { management per firm }\end{array}$ & $\begin{array}{c}\text { Total sum of focus on } \\
\text { value management per } \\
\text { firm }\end{array}$ & $\begin{array}{c}\text { Total sum of control } \\
\text { of value management } \\
\text { per firm }\end{array}$ \\
\hline Chi-Square & 16.783 & 13.770 & 23.841 & 21.342 \\
\hline df & 9 & 9 & 9 & 9 \\
\hline Asymp. sig. & . 052 & 131 & .005 & . 011 \\
\hline
\end{tabular}

The result shows that with a $p$-value of less than This chart shows what is contained in Table 2, 0.05 , only the data on 'focus' and 'handling' 'focus' section, that the firm with the most valshows statistically significant difference across ue management practice is unsurprisingly Cocafirms. Cola ranked at 290.62 and the least being Innoson 
Technical and Industrial Company at 202.55.

Figure 2 shows the level of statistically significant difference of value management practices on the basis of whether value management is internally or externally handled. Here, the Iboko Rice Mill in Izzi Ebonyi State stands out at 291.86, while at the least is Ibeto Petrochemicals at 206.50. It is worthy to note that while the firm in the focus section is a multinational firm and the firm here is a local firm, the both are consumer based firms.

\section{Category 2. Firm location}

Table 4. Descriptive statistics on the collation of question items based on firm location

Source: SPSS (v. 20).

\begin{tabular}{|c|c|c|c|c|c|}
\hline $\begin{array}{l}\text { Parameters } \\
\text { accessed }\end{array}$ & $\mathbf{N}$ & Mean & $\begin{array}{c}\text { Std. } \\
\text { deviation }\end{array}$ & Min & Max \\
\hline $\begin{array}{l}\text { Total sum of } \\
\text { actual usage } \\
\text { of value } \\
\text { management per } \\
\text { firm }\end{array}$ & 509 & 12.3065 & 2.98229 & 5.00 & 20.00 \\
\hline $\begin{array}{l}\text { Total sum of } \\
\text { perceived } \\
\text { usage of value } \\
\text { management per } \\
\text { firm }\end{array}$ & 509 & 12.4695 & 3.02574 & 4.00 & 20.00 \\
\hline $\begin{array}{l}\text { Total sum of } \\
\text { focus on value } \\
\text { management per } \\
\text { firm }\end{array}$ & 509 & 12.3674 & 3.01058 & 5.00 & 20.00 \\
\hline $\begin{array}{l}\text { Total sum of } \\
\text { control of value } \\
\text { management per } \\
\text { firm }\end{array}$ & 509 & 12.3360 & 3.13086 & 5.00 & 20.00 \\
\hline $\begin{array}{l}\text { Location of the } \\
\text { firm }\end{array}$ & 509 & 2.5010 & 1.22735 & 1.00 & 5.00 \\
\hline
\end{tabular}

Table 4 shows the aggregated mean and standard deviation of the question items for the value management practices.

With all the $p$-values above 0.05 , there is no statistically significant difference of value manage- ment practices on the basis of the firm location. Although Eastern Nigeria is relatively homogenous and has no distinct operational variability.

\section{Category 3. Industry type}

Table 6. Descriptive statistics on the collation of question items based on industry type

Source: SPSS (v. 20)

\begin{tabular}{|c|c|c|c|c|c|}
\hline $\begin{array}{c}\text { Parameters } \\
\text { accessed }\end{array}$ & $\mathbf{N}$ & Mean & $\begin{array}{c}\text { Std. } \\
\text { deviation }\end{array}$ & Min & Max \\
\hline $\begin{array}{l}\text { Total sum of actual } \\
\text { usage of value } \\
\text { management per } \\
\text { firm }\end{array}$ & 509 & 12.3065 & 2.98229 & 5.00 & 20.00 \\
\hline $\begin{array}{l}\text { Total sum of } \\
\text { perceived usage of } \\
\text { value management } \\
\text { per firm }\end{array}$ & 509 & 12.4695 & 3.02574 & 4.00 & 20.00 \\
\hline $\begin{array}{l}\text { Total sum of } \\
\text { focus on value } \\
\text { management per } \\
\text { firm }\end{array}$ & 509 & 12.3674 & 3.01058 & 5.00 & 20.00 \\
\hline $\begin{array}{l}\text { Total sum of } \\
\text { control of value } \\
\text { management per } \\
\text { firm }\end{array}$ & 509 & 12.3360 & 3.13086 & 5.00 & 20.00 \\
\hline Industry type & 509 & 1.3988 & .49014 & 1.00 & 2.00 \\
\hline
\end{tabular}

Table 6 shows the aggregated mean and standard deviation of the question items for the value management practices.

Table 7 describes the mean ranks as internally estimated from the Mann-Whitney's U test computation.

With $p$-values at below 0.05 at all question levels, there is a statistically significant difference on all levels of value management practice, with a significantly higher mean ranks for consumer based firms as against construction/engineering firms.

Table 5. Kruskal-Wallis $\mathrm{H}$ result on group difference

Source: SPSS (v. 20)

\begin{tabular}{l|c|c|c|c}
\hline Results & $\begin{array}{c}\text { Total sum of actual } \\
\text { usage of value } \\
\text { management per firm }\end{array}$ & $\begin{array}{c}\text { Total sum of perceived } \\
\text { usage of value } \\
\text { management per firm }\end{array}$ & $\begin{array}{c}\text { Total sum of focus on } \\
\text { value management per } \\
\text { firm }\end{array}$ & $\begin{array}{c}\text { Total sum of control of } \\
\text { value management per } \\
\text { firm }\end{array}$ \\
\hline Chi-Square & 5.944 & 3.494 & 5.597 & 4 \\
\hline df & 4 & 4 & 4.608 \\
\hline Asymp. sig. & .203 & .479 & .231 & .330 \\
\hline
\end{tabular}


Table 7. Mean rank of value management practices per firm industrial type

\begin{tabular}{|c|c|c|c|c|}
\hline Parameters accessed & Industry type & $\mathbf{N}$ & Mean rank & Sum of ranks \\
\hline \multirow{3}{*}{$\begin{array}{l}\text { Total sum of actual usage of value } \\
\text { management per firm }\end{array}$} & Consumer based (CSBs) & 306 & 267.65 & 81901.00 \\
\hline & Construction/engineering (CTBs) & 203 & 235.93 & 47894.00 \\
\hline & Total & 509 & - & - \\
\hline \multirow{3}{*}{$\begin{array}{l}\text { Total sum of perceived usage of } \\
\text { value management per firm }\end{array}$} & Consumer based (CSBs) & 306 & 268.71 & 82225.50 \\
\hline & Construction/engineering (CTBs) & 203 & 234.33 & 47569.50 \\
\hline & Total & 509 & - & - \\
\hline \multirow{3}{*}{$\begin{array}{l}\text { Total sum of focus on value } \\
\text { management per firm }\end{array}$} & Consumer based (CSBs) & 306 & 269.21 & 82378.50 \\
\hline & Construction/engineering (CTBs) & 203 & 233.58 & 47416.50 \\
\hline & Total & 509 & - & - \\
\hline \multirow{3}{*}{$\begin{array}{l}\text { Total sum of control of value } \\
\text { management per firm }\end{array}$} & Consumer based (CSBs) & 306 & 268.38 & 82124.50 \\
\hline & Construction/engineering (CTBs) & 203 & 234.83 & 47670.50 \\
\hline & Total & 509 & - & - \\
\hline
\end{tabular}

Table 8. Mann-Whitney U result on group difference

Source: SPSS (v. 20).

\begin{tabular}{l|c|c|c|c}
\hline Results & $\begin{array}{c}\text { Total sum of actual } \\
\text { usage of value } \\
\text { management per firm }\end{array}$ & $\begin{array}{c}\text { Total sum of perceived } \\
\text { usage of value } \\
\text { management per firm }\end{array}$ & $\begin{array}{c}\text { Total sum of focus on } \\
\text { value management } \\
\text { per firm }\end{array}$ & $\begin{array}{c}\text { Total sum of control } \\
\text { of value management } \\
\text { per firm }\end{array}$ \\
\hline Mann-Whitney U & 27188.000 & 26863.500 & 26710.500 & 26964.500 \\
\hline Wilcoxon W & 47894.000 & 47569.500 & 47416.500 & 47670.500 \\
\hline$Z$ & -2.394 & -2.595 & -2.690 & -2.531 \\
\hline Asymp. sig. (2-tailed) & .017 & .009 & .007 & .011 \\
\hline
\end{tabular}

\begin{tabular}{|c|c|c|}
\hline \multirow{6}{*}{ 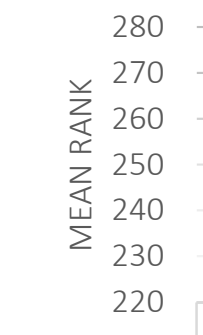 } & \multicolumn{2}{|l|}{267,65} \\
\hline & & \\
\hline & & \\
\hline & & 235,93 \\
\hline & & \\
\hline & Consumer Rased & Construction/Engineering \\
\hline Mean rank & 267,65 & 235,93 \\
\hline
\end{tabular}

INDUSTRY TYPE

Figure 3. "Actual use" mean rank by industry type

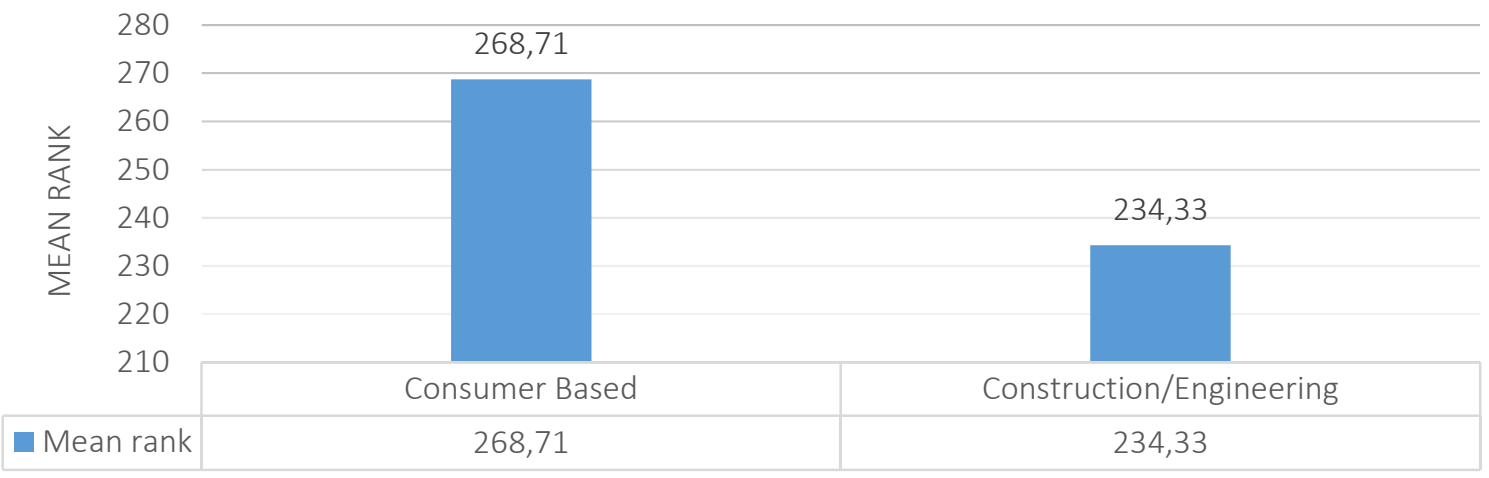

INDUSTRY TYPE

Figure 4. "Perceived usage" mean rank by industry type 


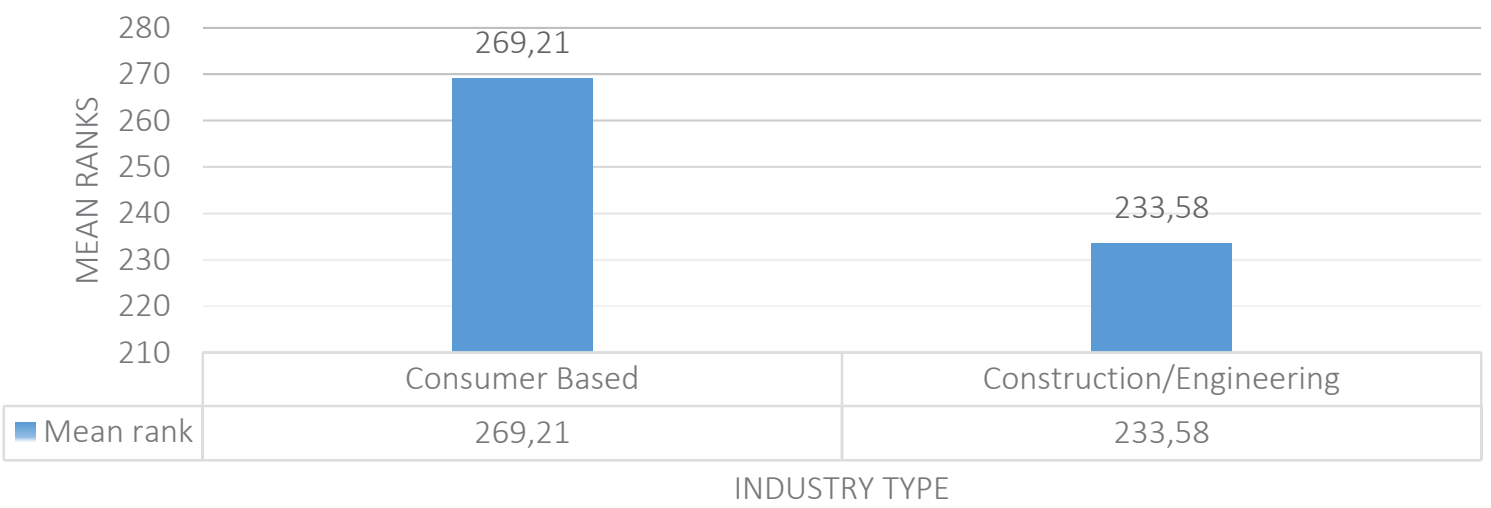

Figure 5. "Focus level" mean rank by industry type

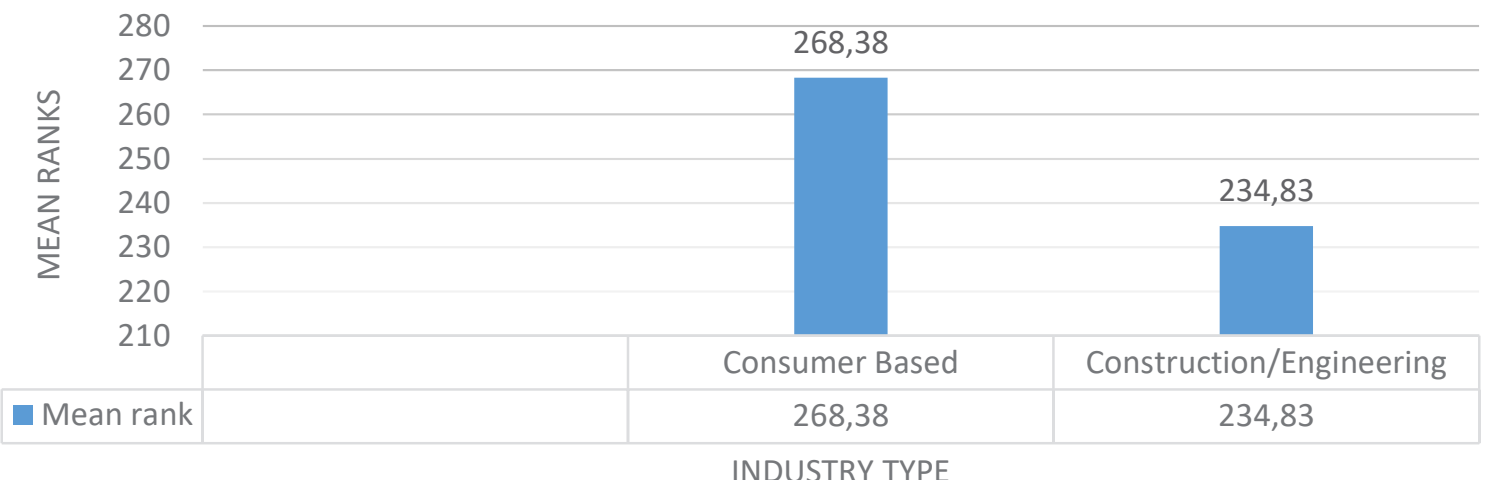

Figure 6. "Level of control" mean rank by industry type

Figure 3 shows a higher mean for the consumer based firms as it has to do with value management practices.

Figure 4 shows a higher mean for the consumer based firms as it has to do with value management practices.

Figure 5 shows a higher mean for the consumer based firms as it has to do with value management practices.

Figure 6 shows a higher mean for the consumer based firms as it has to do with value management practices.

\section{DISCUSSION}

The findings of this study show that on the firm to firm comparison as stipulated in hypothesis 1 , the actual and perceived usage of value management practices are not statistically significant, but the firms' focus and control levels on various val- ue management tools were. The statistically significant results on the level of firms' focus show that consumer based firms (CSBs) have a higher group mean (256.9) as compared to the group mean (247.4) of construction based firms (CTBs). Also, the comparative mean score for control levels of value management practices show that CSBs have a higher mean score of 264.8 compared to CTBs' of 234.3. On the basis of the firms' location as stated in hypothesis 2 , the results show that there is no statistically significant difference amongst mean scores of the various firms. This outcome is probably a result of all firms being situated in the SouthEastern Nigeria, having homogeneous socio-economic characteristics of a developing nation. Lastly, the Mann-Whitney's U dual group analysis of consumer and construction based firms show a statistically significant mean difference between the two groups. The $p$-values for them were actual usage (0.017); perceived usage (0.009); focus level $(0.007)$ and control level (0.011). It should be further stated that the consumer based firms scored a higher mean score than the construction based firm, across all factors. 


\section{CONCLUSION AND POLICY IMPLICATIONS}

The study concludes that consumer based firms do have a higher inclination on the use, focus and control of value management tools. It further shows that this inclination is not based on locational disparities, but on a firm-by-firm and industrial typology comparison. This implies that the comparison of actual usage, perceived usage, focus of, and control of value management is generally higher for firms that directly serve consumers, and not necessarily with regard to where these firms are located. The study also finds that on the firm-by-firm comparison, the level of perceived and actual usage of value management tools were not of statistical significance.

In very clear terms, the subject of value management should be taken with a multidisciplinary approach. Although our findings tilt heavily towards the view that consumer based firms have a higher value management orientation as compared to construction based firm, we do not imply or suggest that researchers in the engineering or project management discipline should refrain from studying the subject. We rather suggest that other disciplines should also develop the interest of pursuing studies in value management. We again wish to state that this is a widely held view (Dumond, 2000; Kearns, 2009; Strack \& Villis, 2002; Verhoef, Doorn, \& Dorotic, 2015).

Also, as a matter of policy, value management as an organizational practice has to be systematic with actual brainstorming and efficient costing techniques. We also emphasize the need for flexibility and dynamism within the process, thereby creating an opening for the various cost reduction and functionality enhancement tools of value management. As without such openness to change, the system would still be taken from a purely monocentric discipline, which would help the development of the discipline.

Lastly, we also do recommend that a study of a larger scope may be necessary. The study could have a similar style and structure with this, but would have to be led by a multidisciplinary team including, but not limited to researchers in engineering, project management, marketing and strategic management. It may also cut across firms in both developing and developed countries, having emphasis on firms such as old and young multinationals like Coca-Cola on the consumer side and Julius Berger on the construction side, this is because these are firms with branches across different nations, but having the same value process. This study properly stratified would show what defines the value management orientation of firms, whether is economy, industry type, age, and size, as well as giving value management the multidisciplinary perspective it sorely requires.

\section{REFERENCES}

1. Aghimien, D. O., Oke, A. E., \& Aigbavboa, C. O. (2018). Barriers to the adoption of value management in developing countries. Engineering, Construction and Architectural Management, 25(7), 818-834. https://doi.org/10.1108/ECAM04-2017-0070

2. Amoush, K. H. (2015). The impact of employing brainstorming strategy on improving writing performance of english major students at Balqa applied university in Jordan. Journal of
Education and Practice, 6(35), 88-92. Retrieved from https://eric. ed.gov/?id=EJ1086359

3. Bowen, P. A., Edwards, P. J., \& Cattell, K. (2009). Value management practice in South Africa : The built environment professions compared. Construction Management and Economics, 27(11), 1039-1057. https://doi. org/10.1080/01446190903280435

4. Bowen, P., Cattell, K., Edwards, P., \& Jay, I. (2010). Value management practice by South
African quantity surveyors.

Facilities, 28(1), 46-63. https://doi. org/10.1108/02632771011011396

5. Charles, I., Nasiri, F., \& Hammad, A. (2017). Evaluating the impact of value management and buildability assessment on construction project delivery. Retrieved from https:// www.researchgate.net/publication/317620678_Evaluating_the _ Impact_of_Value_Management_ and_Buildability_Assessment_on_ Construction_Project_Delivery

6. Curran, P. G. (2016). Methods for the detection of carelessly invalid 
responses in survey data. Journal of Experimental Social Psychology, 66, 4-19. https://doi.org/10.1016/j. jesp.2015.07.006

7. Dhir, K. S. (1987). Formulating management policies for value engineering/value analysis. IEEE Transactions of Engineering Management, 34(3), 161-171.

8. Douglas, A., \& Lubbe, B. A. (2006). Identifying value conflicts between stakeholders in corporate travel management by applying the soft value management model : A survey in South Africa. Tourism Management, 27(6), 11301140. https://doi.org/10.1016/j. tourman.2005.11.007

9. Dumond, E. J. (2000). Value management : An underlying framework. International Journal of Operations \& Production Management, 20(9), 1062-1077. https://doi. org/10.1108/01443570010339154

10. Ellis, R. C. T., Wood, G. D., \& Keel, D. A. (2005). Value management practices of leading UK cost consultants. Construction Management and Economics, 23(5), 483-493. https://doi. org/10.1080/01446190500040711

11. Fallon, C. (1961). Value engineering and product engineering. IRE Transactions on Product Engineering and Production, 5(2), 93-97. https://doi. org/10.1109/TPEP.1961.1136124

12. Feir-Walsh, B., \& Toothaker, L. (1974). Assumptions homogeneity pendence. Educational and Psychological Measurement, 34(4), 789-799.

13. Fong, P. S., Shen, Q., \& Cheng, E. W. (2001). A framework for benchmarking the value management process. Benchmarking: An International Journal, 8(4), 306-316. https://doi. org/10.1108/14635770110403800

14. Gillier, T., Hooge, S., \& Piat, G. (2014). Framing value management for creative projects : An expansive perspective. International Journal of Project Management, 1-14. https://doi.org/10.1016/j.ijproman.2014.11.002
15. Green, S. D., \& Liu, A. M. M. (2007). Theory and practice in value management: A reply to Ellis et al. (2005). Construction Management and Economics, 25(6), 649-659. https://doi. org/10.1080/01446190601161473

16. Hashempour, Z., Rostampour, M., $\&$ Behjat, F. (2015). The effect of brainstorming as a pre-writing strategy on EFL advanced learners' writing ability. Journal of Applied Linguistics and Language Research, 2(1), 86-99. Retrieved from https:// www.semanticscholar.org/paper/ The-Effect-of-Brainstorming-asa-Pre-writing-on-EFL-Hashempour-Rostampour/c4ad173e7a156b5496ae17e6125089fc8552af48

17. Hayes, A. F. (2018). Introduction to mediation, moderation and conditional process analysis (2nd ed.). New York: Guilford Publishers.

18. Hyatali, N., \& Pun, K. F. (2015). Value Management in academic libraries: A case study value. The Journal of the Association of Professional Engineers of Trinidad and Tobago, 40(1), 26-33. Retrieved from https:// www.researchgate.net/publication/287988573_Value_Management_in_Academic_Libraries_A_ Case_Study

19. Kassa, A. O. (2018). Value analysis and engineering reengineered (1st ed.). Florida, United States of America: CRC Press.

20. Kearns, P. (2009). Strategic value measures and management tools. In HR Strategy (pp. 141-161). https://doi.org/10.1016/b978-185617-815-0.10007-9

21. Kelly, J., \& Male, S. (1993). Value management in design and construction (1st ed.). United Kingdom: E \& FN Spon.

22. Kelly, J., Male, S., \& Graham, D. (2015). Value management of construction projects. In Value Management of Construction Projects (2nd ed.) (pp. 173-190). John Wiley \& Sons, Ltd.

23. Kissi, E., Boateng, E. B., \& Badu, A.-K. (2016). Principal component analysis of challenges facing the implementation of value engineering in public projects in developing countries. International Journal of Construction Management, 17(2), 142-150. https://doi.org/10.1080/1 5623599.2016.1233088

24. Latour, B. (2005). Reassembling the social: An introduction to actornetwork-theory (1st ed.). Oxford: Oxford University Press.

25. Leung, M., Ng, S. T., \& Cheung, S. (2002). Improving satisfaction through conflict stimulation and resolution in value management in construction projects. Journal of Management in Engineering, 18, 68-75. Retrieved from https://ascelibrary.org/ doi/10.1061/\%28ASCE\%290742$597 \mathrm{X} \%-$ 282002\%2918\%3A2\%2868\%29

26. Mann, H., \& Whitney, D. (1947). On a test of whether one of two random variables is stochastically larger than the other. The Annals of Mathematical Statistics, 18(1), 50-60. Retrieved from https://projecteuclid.org/euclid. aoms/1177730491

27. Mcgeorge, D., \& Angela, P. (2002). Construction management (2nd ed.). Oxford, United Kingdom: Blackwell Publishing Company.

28. Oke, A. E., \& Ogunsemi, D. R. (2011). Value Management in the Nigerian construction industry : Militating factors and the perceived benefits. In Second International Conference on Advances in Engineering and Technology (pp. 353-359). Retrieved from https://www. researchgate.net/publication/266575443_Value_Management_in_the_Nigerian_Construction_Industry_Militating_Factors_ and_the_Perceived_Benefits

29. Oke, E. A., Aghimien, O. D., \& Olatunji, O. S. (2015). Implementation of value management as an economic sustainability tool for building construction in Nigeria. International Journal of Managing Value and Supply Chains, 6(4), 55-64. https://doi.org/10.5121/ ijmvsc.2015.6405

30. Perera, S., Hayles, C. S., \& Kerlin, S. (2011). An analysis of 
value management in practice: The case of Northern Ireland's construction industry. Journal of Financial Management of Property and Construction, 16(2), 94-110. https://doi. org/10.1108/13664381111153097

31. Spaulding, W. M., Bridge, A. \& Skitmore, M. (2007). The use of function analysis as the basis of value management in the Australian construction industry. Construction Management and Economics, 23(7), 723-731. https://doi. org/10.1080/01446190500040679

32. Strack, R., \& Villis, U. (2002). $\mathrm{RAVE}^{\mathrm{TM}}$ : Integrated value management for customer, human, supplier and invested capital. European Management Journal, 20(2), 147-158. https:// doi.org/10.1016/S02632373(02)00025-7

33. Thangavelu, K., \& Brunner, E. (2007). Wilcoxon-Mann-Whitney test for stratified samples and Efron's paradox dice. Journal of Statistical Planning and Inference, 137(3), 720-737. https://doi. org/10.1016/j.jspi.2006.06.005

34. Thiry, M. (2001). Sensemaking in value management practice. International Journal of Project Management, 19(2), 71-77.
https://doi.org/10.1016/S02637863(00)00023-5

35. Verhoef, P. C., Doorn, J., \& Dorotic, M. (2015). Customer value Management: An overview and research agenda. Marketing ZFP, 29(2), 105-122. https://doi. org/10.15358/0344-1369-2007jrm-2-105

36. Zhang, B., \& Zhang, Y. (2009). Mann-Whitney U test and Kruskal-Wallis test should be used for comparisons of differences in medians, not means: Comment on the article by van der Helmvan Mil et al. Arthritis and Rheumatism, 60(5), 1565. https:// doi.org/10.1002/art.24497 